\title{
The Visual Elements in The Pohon Beringin Figure of the Kelantan Shadow Play
}

Fiona Wong E Chiong, Department of Art and Design, School of Arts, Sunway University, Malaysia

fionaw@sunway.edu.my

and

Ghulam-Sarwar Yousof, Cultural Centre, University of Malaya, Kuala Lumpur.

gsyousof@um.edu.my

(C) 2018 Cultural Centre, University of Malaya. This work is licensed under the terms of the Creative Commons Attribution (CC BY-NC-ND) (https://creativecommons.org/ licenses/by-nc-nd/4.0/)

Received 02 October, 2018; Accepted 10 December, 2018; Published 31 December, 2018.

\begin{abstract}
This paper examines the likely synthesis of conceptions related to mountains and trees in different belief systems (indigenous animistic, Hindu-Buddhist and Islamic) in the mountain or tree-shaped figure known as gunungan or kayon of the classical Indonesian shadow play Wayang Kulit Purwa and pohon beringin of the Malaysian Wayang Kulit Kelantan. Such a figure belongs uniquely to these two forms of puppetry although in Indonesia, the use of the kayon has spread beyond the shadow play into other newer forms of traditional theatre, as well as into general use.

Following a brief discussion of possible origins, meaning and significance of the mountain-tree figure in the Javanese and Kelantan shadow play, this paper presents a detailed visual analysis of two types of Kelantanese pohon beringin puppets. The first is purely arboreal while the second contains living creatures. This article's goal is to establish possible connections with other traditional art forms, such as batik, that are rooted in a common heritage of motifs and symbols.
\end{abstract}

Key Words: Wayang Kulit Purwa, Wayang Kulit Kelantan, Kayon, Gunungan, Pohon Beringin, Shadow Play Designs.

\section{Introduction}

By far the most important shadow play (Wayang Kulit) figures in Java, Bali, neighbouring Indonesian islands and the Malay Peninsula, are the tree- or leaf- shaped ones. They are known as gunungan-kayon in Java and pohon beringin in Kelantan. Out of a considerable range of such figures connected with regional and localised Wayang Kulit forms in the region, in keeping with dramatic content, the most outstanding examples 
are to be seen in the classical Javanese Wayang Kulit Purwa, while in peninsular Malaysia the pohon beringin is used only in Wayang Kulit Kelantan. The Indonesian designations, gunungan and kayon, used interchangeably throughout the islands, originated from two separate key images, that of mountain (gunung or gunungan) and tree (kayon), while the Malaysian pohon beringin (Indonesian waringin) is based solely on the idea of a banyan (ficus benjamina) tree (Wilkinson, 1957: 127).

The Southeast Asian shadow play and its constituent elements-dramatic repertoire and puppets as well as performance elements - indicate strong connections with and influences from several cultures beyond the immediacy of the region, particularly from South Asia, the Middle East and the Near East. In seeking the possible genesis of the gunungan and pohon beringin figures, it may be worthwhile to briefly examine the significance of mountains and trees in those regions. Firstly, this establishes a background for the present discussion. Secondly, to establish possible impacts upon the development of the gunungan. Thirdly, given the development of the shadow play itself within the Indonesian-Malay world (Nusantara), it is most likely that the Malay figure had its roots in the Javanese one (Ghulam-Sarwar, 2015: 12-40).

\section{Sacredness of Trees and Mountain and their Symbolism}

In Hindu, Buddhist and Jain cosmologies the mountains Kailasa and Meru are seen as physical, metaphysical and spiritual centres of the universe. Kailasa and the mythic Mt Meru, both located in the Himalayas, are revered in Hinduism as homes, respectively, of the gods Shiva and Brahma. Additionally, Meru, also known as Sumeru, with the first syllable meaning excellent, great or wonderful, is sacred in Mahayana Buddhism as the home of Indra, who is identified with Sakra, the lord of Tusita Heaven, where potential Buddhas await before coming to this world for their final incarnation (The Seeker's Glossary, 1998: 290 \& 637). From South Asia the meanings and symbolism attached to Mt Meru in particular spread to Southeast Asia in the early centuries of the Common Era, and to this day have resonance in the region. Indonesian tradition maintains that Java itself was built with the transfer of parts of Mt Meru or Sumeru.

Mount Hira, also known as Jabal Nur or the Mount of Light, just outside the holy city of Mecca, has a central place in Islam for it was in a cave on its peak that Prophet Muhammad received divine revelations (al-wahy). Islamic mysticism (Sufism) assigns important symbolism to the mythical Mt Qaf or Kaf (Tresidder, 2004: 329) in the Caucasus Mountains, where lives the fabulous bird Simurgh (Chevalier and Gheerbrant, 1996: 684). This particular mountain has been accorded a wider and deeper mystical meaning in Shabistari's Secret Garden of Mystery, as well as in Farid-ud-din Attar's mystical allegory, The Conference of Birds, which traces the soul's arduous journey in search for Allah (Chevalier and Gheerbrant, 1996: 883-4).

Like mountains and elevated places, trees are regarded as sacred in many cultures, with each of the world's major traditions having its own sacred tree, be it the bodhi tree under which Siddharta attained enlightenment (nirvana), the Tree of Life, the Tree of Knowledge of Good and Evil, or Sidrat-al-Muntaha the Lote Tree, which marks the Boundary of the seventh heaven, where Muhammad during his Night Journey (miraj) received the command from God for the five daily prayers. This episode is mentioned in chapter 5 verses 10-18 of the Holy Quran. In the light of these examples, Fontana's 
summary is pertinent: "The tree is one of mankind's most potent symbols. It is the embodiment of life, the point of union of the three realms, heaven, earth and water, and a world axis around which the universe is organized" (Fontana, 1993: 100).

\section{The Tree-Mountain Figure in Javanese Shadow Play}

Despite the universal and vital symbolic value of mountain and tree separately, as well as in combination as seen in the kayon, such a figure is found neither in any Indian form of the shadow play, nor in Southeast Asian ones apart from those in Indonesia and Malaysia where the pohon beringin is based entirely upon the idea of a tree. Given such a situation, it is entirely conceivable that such a mountain-tree figure developed uniquely within Nusantara, with the incorporation and fusion of indigenous and external symbols from major cultures discussed above.

It is noteworthy too, that in conformity with new dramatic materials and alternative designs of shadow puppets in the classical shadow play styles within Java and beyond such as Bali, Lombok, Kalimantan, as well as in Kelantan, the gunungan has shifted considerably in design. This is the case also in secondary forms of shadow play, such as Wayang Kulit madya and Wayang Kulit gedog, which are based upon non-epic dramatic materials. It is also the case for new forms of shadow play, such as Wayang Kulit Katholik and Wayang Kulit Sang Kancil, as well as in non-shadow play puppet theatre forms such as Wayang golek, and Wayang klitik. By extension the kayon also appears occasionally in human theatre genres such as Wayang wong or in dance performances.

It is necessary to look, if only in passing, at classical examples due to parallels in conception between, and likely aesthetic influences of, Javanese examples and/upon the Kelantanese pohon beringin. In comparison with those from Java (see Figure 1), the highly simplified Balinese gunungan essentially

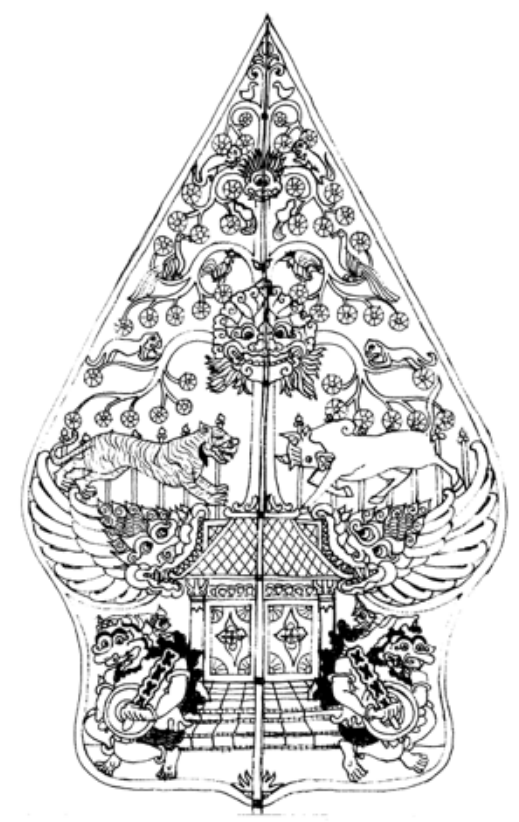
represent a stylised tree (see Figure 2), while the Malaysian pohon beringin occur both in purely arboreal form as well as in more complicated shapes incorporating images of certain living creatures. These latter figures are, however, nowhere as complex as those in Java.

Figure 1. A sketch of a Javanese gunungan puppet depicting a tree behind a gate guarded by two demon giants and is more having male qualities. This is one of the two types, known as gunungan gapuran (Drawing by Wong, 2018) 


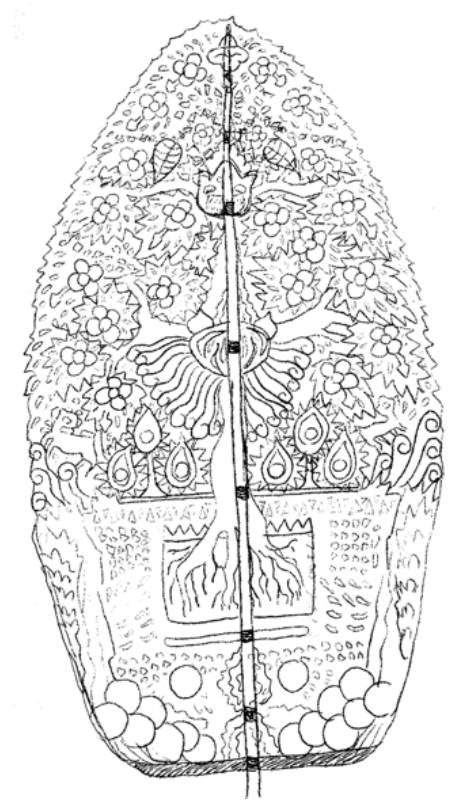

Figure 2. A sketch of a Balinese kayon puppet, its tree resembling more realistically an image of a tree with stronger nature motifs depicted (Drawing by Wong, 2018)

\section{Functions of the Gunungan/Pohon Beringin}

The puppeteer (dalang), upon taking his position screen-centre in the theatre (panggung), has the onerous task of "bringing life" into the cosmos. This he does by plucking the kayon from its position on the banana stem, causing it to vibrate in tremulous fashion, and then moving it from side to side, its shadow falling large on the screen, then withdrawing it altogether momentarily before placing it back in its original position. With the universe thus brought to life, the puppeteer's plot involving gods, demons, human beings and possibly members of other species as characters, can begin to unfold. At the end of a performance the kayon is returned to its original position.

On a more mundane level, the gunungan puppet serves several roles as a stage property. It can still be a mountain or, used in a pair, it can represent a cave. It can also be a single tree or a forest, or it can stand for any kind of obstacle. Waved in circles it represents a huge flame or a thunderstorm, and so on. Wayang Kulit Kelantan's pohon beringin is much less dramatically used, serving principally to mark the opening and closing of performances.

\section{Symbolism}

The pohon beringin is deemed the most important of all puppets in the Wayang Kulit Kelantan as it is a symbol of life and "represent the cosmos in miniature and a microcosm of the universe" (Kingham 2006: 64). It is visually divided into three levels and a large tree motif stands in the centre surrounded by flora and fauna motifs, such as birds, fish, crocodiles, elephants, monkeys, snakes, trees, branches, flowers, buds, fruits, sky, water and flames, mountain range among others. The three level cosmos represents the three cosmic levels, with water creatures such as fishes, serpents or crocodiles at the bottom level representing water; land animals in the middle level rep- 
resenting earth; birds at the top level representing air, sky or sprit; and, ultimately the flame (fire) (Kingham 2006: 68 \& 69; Rahimidin 2013: 60).

A universal symbol, this tree motif is popularly known as the "Tree of Life" and is common in many cultures and used in many media. Scholars writing about textiles of Southeast Asia, described the tree motif as a "symbol of totality, the cosmic whole, or the unity of upper and lower worlds, [...] seen in many groups" (Gittinger, 1985: 33). Maxwell (1990) states:

In many cultures the tree motif appears to symbolize an axis mundi, a link between Lower and Upper worlds. ${ }^{1}$ Nature provides convenient objects to represent the cosmos and the tree has been a prominent symbol linking earth (the abode of humans) with the heavens (the dwelling place of the gods). The tree often appears on top of or growing out of a mountain of rocks, also a symbol of the link between the two worlds. The gods and ancestors reside on the peak of the cosmic mountain at the centre of the world or axis of the universe, in the Hindu world at Mount Meru or in the Greek world at Mount Olympus. The imagery of the world mountain and cosmic tree is so intertwined that they have sometimes become interchangeable and interconnected symbols. (Maxwell, 1990: 106)

The near-realistic renderings of nature and life creatures placed at various tiers within the pohon beringin puppet symbolises the different levels in the cosmic world, as Maxwell (1990) states:

A mythical bird perched in the tree is another symbol linking the earth
with the world above. As a symbol of the soul (Cook 1974), a bird or ea-
gle sometimes nests in the cosmic tree. In a further development of this
symbolism, the serpent or mythical snake represents the Underworld and
is sometimes depicted entwining the cosmic tree. It may spring from the
earth or from the primodial water like the tree-related image, the lotus.
Each symbol or combination of symbols becomes a pictorial device to
reduplicate the universe. In addition to these ideas of a heavenly axis and
its link with the realm of the ancestors and creators, the tree of life is of-
ten a symbol of fertility, prosperity and well-being. (Maxwell, 1990: 106)

\section{Shapes and Forms in Pohon Beringin}

Wayang Kulit Kelantan, in its brief recorded 'history' over the past fifty years or so demonstrates some changes and variations in the overall design of its puppets including the pohon beringin. Evidence in the form of photographs from around 1900 (Skeat) and 1950's (Cuisinier) indicate that the puppets were relatively simple. Oral evidence confirms that certain changes came into the puppets from the 1960's principally resulting in the puppets becoming refined and more attractive.

Typically a leaf-shaped figure with a pointed tip at the top resembling an "upsidedown-heart-shape" in the likes of a Javanese gunungan puppet, the pohon beringin is made of cow hide cleaned and polished, and then carved and punched into displaying 
intricate motifs and patterns. Although the actual shape, size and design of the pohon beringin figure vary from one puppet to another, the average size of the pohon beringin - measuring up to $50 \mathrm{~cm}$ in height and $30 \mathrm{~cm}$ in width - is generally adhered to by the craftsmen. A bamboo rod is attached vertically to the spinal part of the puppet and on its back using strings (Ainu \& Mohd. Azmi 1996: 64). The pohon beringin puppet is painted with various colourful synthetic colour enamels, nowadays usually "magicink" or permanent marker inks. The preference or choice of colours may vary from a puppet maker to another. ${ }^{2}$

\section{Two Basic Forms of Design}

The pohon beringin puppet could be classified into two basic forms of design: the first type an arboreal design which does not possess any figurative image but only natural, organic motifs and patterns; the second type consisting of figurative representations resembling living creatures from the natural environment in varying sizes (Kingham, 2006: 66). Influence of the motifs and patterns on the pohon beringin puppet design might have stemmed from Javanese batik designs as "painted designs on antique wayang puppets may show some of the classic batik patterns in use at the time, some dating back to the eighteenth century" (Thompson 2007: 147). Hence, references to the Javanese traditional batik designs will be made during the discussion of the two types of pohon beringin designs.

\section{i) Arboreal Design}

This type of pohon beringin design portrays an arabesque of simplified and stylised organic shapes forming abstract motifs not reflective of any living forms. These abstract motifs are positioned and patterned in a repetitive manner thereby creating a mosaic-like effect or optical illusion. Kingham (2006) indicates that "each item is chosen to be blended together into the 'completeness of the whole' that always seemed to result in creating a sense of serenity", which ultimately reflect the "uniqueness of the visual art of Islam" (70) as Islam encouraged abstraction into non-figurative motifs and patterns. The pohon beringin puppets by dalang (or puppeteers) such as the late Pak Hamzah bin Awang Amat ${ }^{3}$ and Pak Eyo Hock Seng ${ }^{4}$ are examples of this type of arboreal design (see Figures 3 \& 4). 


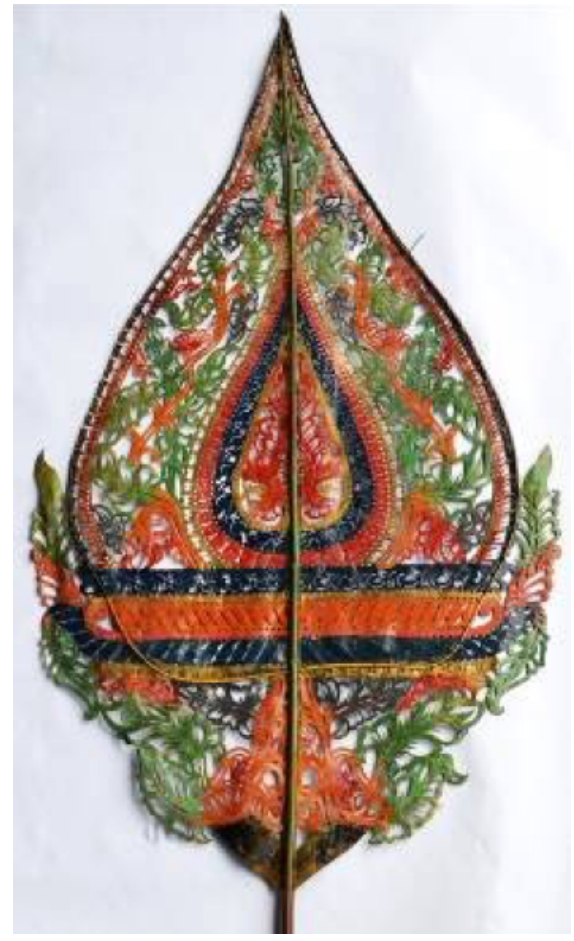

Figure 3. A pohon beringin puppet by Pak Hamzah with highly intricate carvings of abstract forms and shapes, made approximately in the 1970s. (Photograph by Wong)

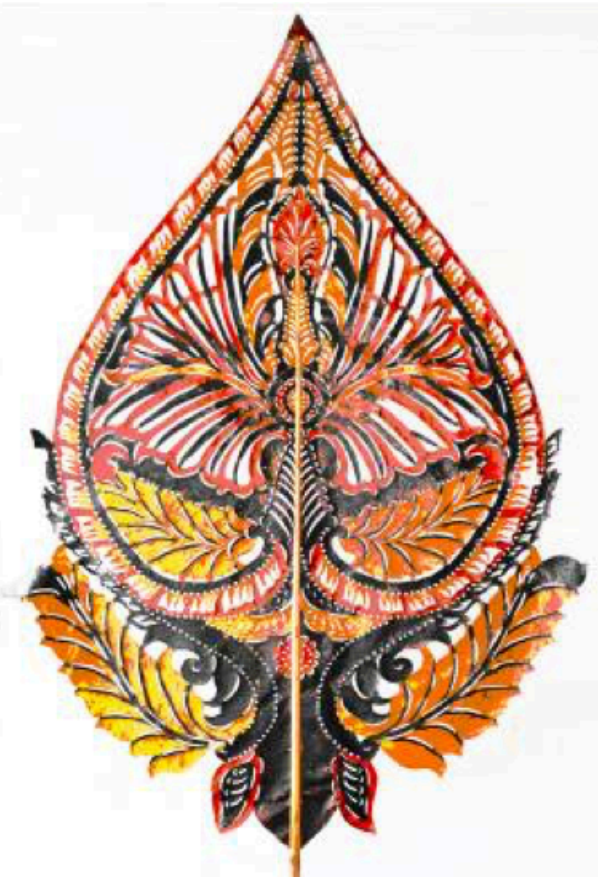

Figure 4. A pohon beringin puppet from Ghulam-Sarwar's collection depicting abstract forms and shapes. It was made by Pak Eyo Hock Seng probably during the 1980s. (Photograph by GhulamSarwar)

Pak Hamzah's pohon beringin puppet (see Figure 3) is carved in a highly intricate manner emphasising mainly non-living forms - particularly tendrils and floral motifsand an absence of figurative motif portraying living forms. The core of the puppet is akin to the shape of a fruit (such as a peach) cut in half, reflecting a symmetrical arrangement of motifs mirroring the left and the right in exact resemblance. The rest of the puppet is filled with mainly motifs of swirling leaves and flowers, intercepted by abstract and geometrical motifs segregating the puppet into a three-tier structure. The ornamentation treatment of the puppet is highly intricate, complex, and detailed. The colours used are typically colours from nature, such as green, blue, orange, red and yellow, contrasting with each other yet co-existing in harmony.

Similarly, Pak Eyo Hock Seng's pohon beringin puppet (see Figure 4) also resembles a half-cut fruit and employs an ornamental design approach. However, the patterns and design differ greatly from those of Pak Hamzah's. Pak Eyo Hock Seng's pohon beringin puppet design in the centre is filled with various types of curvy lines and motifs (although much larger in size) placed in such a way that it resembles a figurative but abstracted form such as a bird or butterfly with its wings opened up and stretched 
outwards, a perfect display of a mirror image and symmetry. There are repetitive motifs that surround the centre image and frames the entire space, giving a kind of emphasis and focus on the centre display. Besides, the lower part of the puppet is bordered with a large-shaped fern or leaf, which also tends to resemble wheat. The range of colours used is inclined towards the warm colour scheme, mainly highlighting the colours yellow, orange, and red, as well as in between certain spaces, black.

It is apparent that this type of arboreal designed-pohon beringin-also exudes strong Javanese influence and resembles that of the Indonesian batik as well. In Pak Hamzah's pohon beringin puppet design, the highly ornate and intricate motifs seem to resonate with the motifs and patterns found in various traditions of Indonesian batik, such as tendril patterns known in Java as semen ${ }^{5}$, intersperse with simpler but repetitive patterns of floral or abstract motifs, with an emphasis on geometric designs typical of Malaysian isen motifs (see Figure 5) in batik (Batik Design: Traditional Textile of the Malay World, 1993: 65 \& 77).
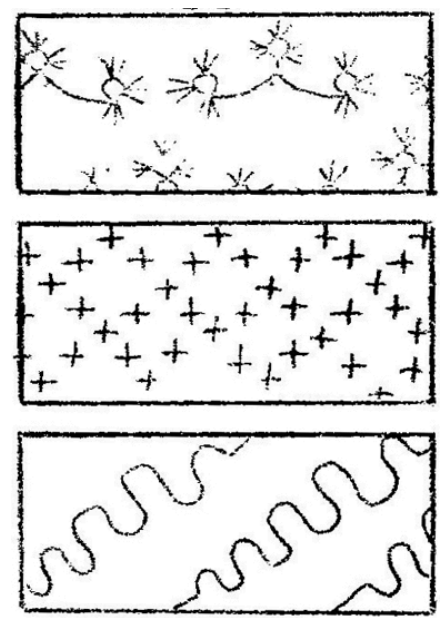

Figure 5. Small motifs called isen, are used to fill up open spaces in a batik layout with decorative ornaments, animals or plants (Batik Design: Traditional Textile of the Malay World, 1993: 77)

The abstraction of floral and tendril patterns could have been the result of Islamic influence with the advent of Islam in the Malay peninsula since the $14^{\text {th }}$ century. ${ }^{6}$ Islamic appreciation for God's creation through understanding of the natural surrounding has encouraged artists to continuously be inspired by their surroundings and create designs in their arts based on nature (Norwani 2016: 167).

\section{ii) Figurative Design}

The other type of pohon beringin design contains figurative representations of living things from the natural environment. A pohon beringin figure from Ghulam-Sarwar's collection (see Figure 6) is an example of a near-realistic rendering of figurative representations drawn from the natural environment, usually in a symmetrical or mirroredreflection type of composition. This puppet is designed with a three tiers division representing the three level cosmos: the lowest tier, representing the waters, comprises four fishes evenly aligned underneath two crocodiles in a symmetrical arrangement and all facing the central vertical axis; the middle tier, representing the earth, depicts land creatures in particular two elephants and two monkeys which are also symmetrically 
aligned and facing the central vertical axis; the upper tier, representing the sky, does not, however, have a clear demarcation but is signified by two large birds resembling the phoenix and each perched on a tree branch, heavily surrounded by an intricate display of curvy and swirly foliage. A myriad of harmonious colours ranging from shades of dark green to crimson orange, as well as black, are applied throughout the design. Intricate motifs of foliage are portrayed in shades of dark green; birds and fishes in crimson orange; monkeys, elephants, the central tree motif and the outer leaf-shaped outline of the puppet in black.

Similarly, the pohon beringin puppet by Pak Yusoff ${ }^{7}$ (see Figure 7) is also divided into three tiers symbolising the three cosmic levels but consists of a different grouping of figurative representation. At the lowest tier, representing water, are two small fishes underneath two large dragon- or serpent-like creatures (naga), each facing outwards respectively to the left and right, while their large long bodies twirl around the horizontal axis. At the middle tier, two dynamic-looking elephants with raised trunks and a feet stood below two larger birds perched on the branches against an intricate foliage pattern. This pohon beringin is rather unique in design because naga figures are not always incorporated as it is a more sacred symbol compared to other more common living creatures such as fishes, elephants and birds. The colours on this puppet range from different degrees of red, orange, and green, as well as single colours yellow and black.

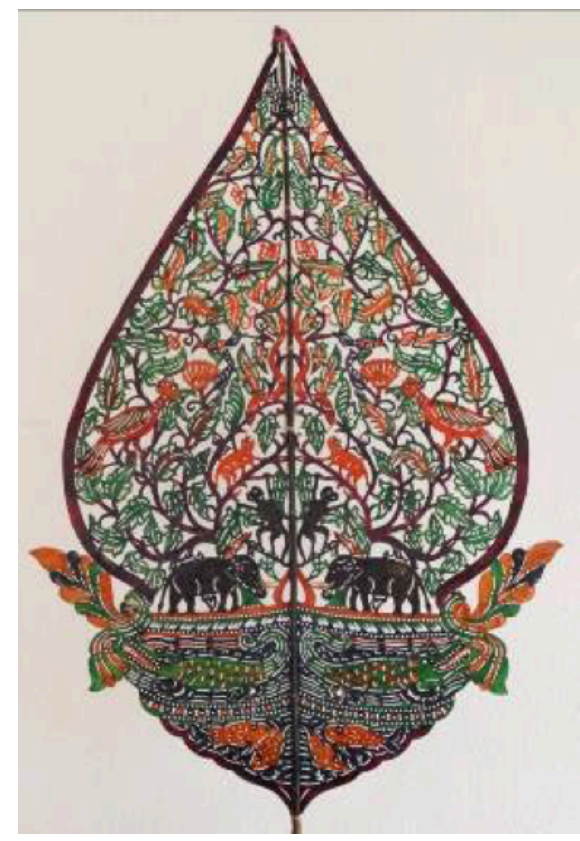

Figure 6. A pohon beringin puppet by Pak Hamzah depicting figurative animals and foliage from Ghulam-Sarwar's collection, made approximately in the 1970s. (Photograph by GhulamSarwar).

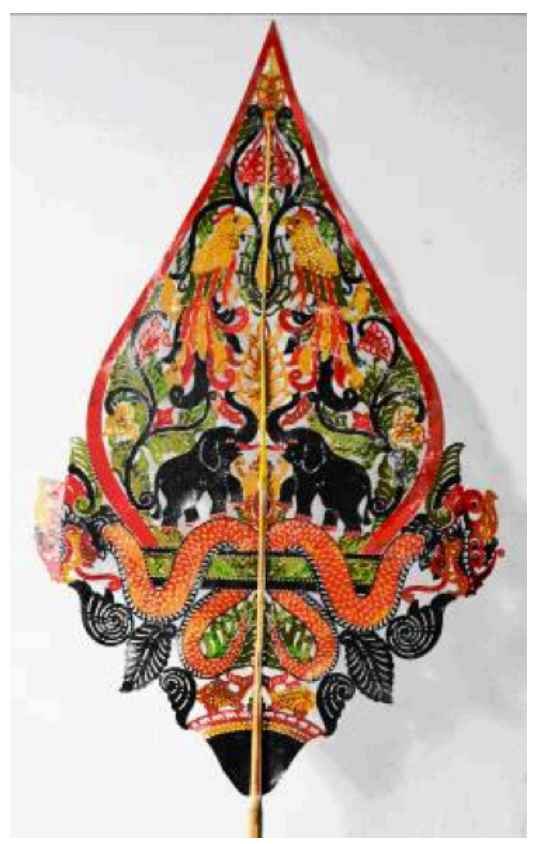

Figure 7.A pohon beringin puppet with a different twist of design portraying slightly larger figurative elements. It is made by Pak Yusoff probably during the 1980s. (Photograph by Ghulam-Sarwar). 
It can be posited that the pohon beringin puppet in Wayang Kulit Kelantan could have been influenced by the kayon (tree) or gunungan (mountain) puppet in Wayang Kulit Purwa because the latter is also a large leaf-shaped leather puppet mythical symbols and animals carved and painted on it. The design of a Javanese gunungan puppet ${ }^{8}$ (see Figure 1) shows a symmetrical mirror-like composition with figurative imageries of living creatures such as tigers and bulls, the Cosmic Tree or Mountain of Life in the middle, spread out winged patterns, and a highly intricate curvy tendrils or foliage patterned background. A slight variation of the second type of puppet design is the difference in the beasts (one of it a tiger and the other a bull), garuda-like faces with wings, two heads on the tree of life, and its standing on a small architectural structure, and the two demon giants guarding the palace gate.

Inspired by the Javanese shadow puppet play, Maxwell and Maxwell9 (in Gittinger 1989: 140) describe the gunungan or kekayon motif evident on a Javanese kain panjang as follow:

The smaller kekayon [motifs on the kain panjang] depict various fragments of the cosmic totality: the water Lower World of fish, crabs, frogs, and snakes below the sacred lotus with entangled roots; the Upper World of birds, flowering trees, and the sun; and the symbolic cosmic axis of the flowering tree entwined by the serpent-snake, its branches filled with animals and birds, and flanked by noble beasts such as the elephant and tiger. The tree rises out of a temple-pavilion, which also represents Mount Meru, the cosmic mountain at the center of the universe. (Maxwell, 1990: 106)

The figurative type pohon beringin indicates strong Javanese influences. The compositional design elements or motifs found on this type of pohon beringin resemble those on traditional Javanese batik. It consists of intricate figurative motifs and patterns of nature, flora and fauna, living and non-living things. For example, an Indonesian kain panjang from Yogyakarta is decorated with a semen ("tendril") design consisting of a mythical naga and floral motifs. Other batik designs are filled with highly stylised mythical animals in the semen range such as insects, deer, snakes, lions, elephants, geese, and phoenix (Batik Design: Traditional Textile of the Malay World, 1993: 64 \& 65). The naga motifs (see Figure 8) as well as the elephants and phoenix figures, stylised differently, also appear in Pak Yusoff's pohon beringin puppet. However, the naga motif is more prominent than the other figures on the puppet. A vernacular symbol in the Southeast Asian region, the naga motif is believed to "symbolise water and the underworld" (Batik Design: Traditional Textile of the Malay World, 1993: 72).

Another example is a kain panjang from Cirebon, Java, revived following Cirebon's old court tradition. It displays stylised motifs, in particular wadas (Chinese motif of layered rock or coral), combined with megamendung (cloud pattern) that form a friezelike design of a taman arun (fragrant garden) characteristic of meditative landscapes of Cirebon's rulers. It also displays "blue, balloon-like shapes... reminiscent of the gunungan or kayon, a tree of life motif that also functioned as a crucial element in wayang (shadow puppet theatre)... the shapes are filled with sinuous trees, monkeys frolicking in their branches" (see Figure 9), and "representation of garudas and nagas, 
mythical bird- and snake-like creatures that are of Hindu derivation but rendered here in Chinese style" (The Art Institute of Chicago, 2007: 63 \& 64).

From these two Javanese batik design examples, it could be established that the Kelantanese pohon beringin may have been inspired by similar motifs evident in traditional Javanese batik designs, influenced by imported Indian textiles such as the Gujerati silk patola. ${ }^{10}$ The patola was regarded as an important source of inspiration for the decoration of batik and highly valued in Southeast Asia during the 15th century (Batik Design: Traditional Textile of the Malay World, 1993: 18).
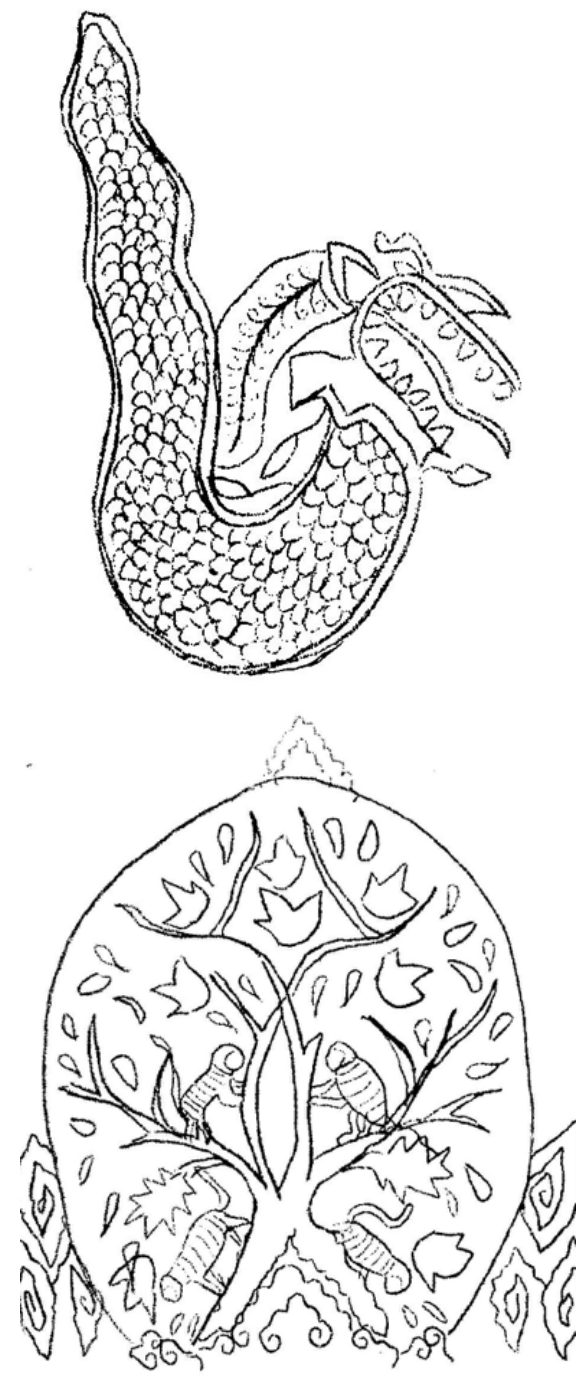

Figure 8. A sketch of a stylized naga motif depicted in an Indonesian kain panjang illustration (Batik Design: Traditional Textile of the Malay World, 1993: 72). The naga is used as a repetitive and symmetrical pattern against a heavily ornamented background of floral or foliage designs (Drawing by Wong, 2018).
Figure 9. The tree-of-life, sketched in a stylized blue balloon-like gunungan or kayon. It is one of the main design motifs in a revived Javanese (Cirebon) textile that displays patterns and motifs in particular wadas (Chinese rocks), megamendung (cloud), and taman arun (fragrant garden) among others. These design elements appear in a kain panjang from Cirebon, Java in The Art Institute of Chicago (2007: 64) (Drawing by Wong, 2018).

While the two figurative pohon beringin puppets shown at figures 6 and 7 differ from each other in terms of design style, scale, proportion, and colours, there are in fact similarities in the form, design elements and motifs used. The common visual characteristics of pohon beringin puppets generally include an overall form shaped like a leaf; a 
design surface divided into three tiers, each tier symbolising a level of the cosmos; symmetrical layout that reflects the same intricate designs mirroring both the left and right sides; and intricate motifs that depict particular living figures (symbolic, mythical animals) and non-living figures (tendrils and floral motifs) derived from nature. For example, in both puppets, apart from the similar and recurring floral and plant motifs, the elephant motif is used to represent the earth while the bird motif is used to represent the sky realm in the three-tier hierarchical cosmology. There are other interchangeable symbolic motifs such as the naga or fish used by puppet makers to represent the lower tier of the three-tiered cosmological structure - the waters, symbolically the underworld. It is, therefore, apparent that the puppet maker may decide to place any suitable motif within the three-tier structure as long as it serves to symbolically represent Hindu cosmology.

Based on the similarities of the motifs and compositional elements, it can be posited that the gunungan or kayon motif evident on the Javanese traditional batik with Indian influence is likely to have inspired and lent its design and symbolism to the Kelantanese figurative pohon beringin, replicating a figurative but stylised tree shape branching out into three levels surrounded by intricate motifs of tendrils and foliage interspersed with animals of the waters, land and air. Another similarity observed is the level of intricacy depicted on the Kelantanese pohon beringin and Javanese traditional batik. Both designs are highly intricate compositions filled with detailed motifs in various colours, symbolic of nature.

Hence, it is apparent that the designs evident on both the arboreal and figurative types of pohon beringin of Wayang Kulit Kelantan are indigenous-inspired but also exude strong Javanese influence. However, the first type or arboreal design pohon beringin are more Islamic-influenced resulting in a design that, although still structured in a three-tier composition, comprises only non-figurative motifs from nature, such as floral, tendrils and foliage. On the contrary, the second type or figurative design pohon beringin could be derived from the Indian-influenced traditional Javanese batik.

\section{Conclusion}

There are two types of gunungan or pohon beringin puppets in Wayang Kulit Kelantan, the first arboreal and the other containing figurative motifs representing living beings from the natural environment in three levels of the cosmos. Both of these types have strong connections with, as well as aesthetic influences from, the Javanese and possibly the Balinese gunungan. This is something that goes back to the almost certain spread of the shadow play from Java into neighbouring Indonesian islands including Bali, Lombok and Kalimantan and beyond that into the Malay peninsula. This can be seen in terms of the overall Indonesian cultural influence in the northern reaches of the Malay peninsula.

The precise origins and history of Wayang Kulit Kelantan remain unknown due to lack of evidence. Connections between the Javanese Wayang Kulit Purwa, several styles of Balinese shadow play, and Wayang Kulit Kelantan, however, are confirmed by oral tradition as well as evidenced by the Ramayana-based repertoire (Wayang Kulit Kelantan does not use the Mahabharata), the indigenous mythology involving figures such as Semar, the rituals marking the opening of performances, special types of spiritual 
performances, and the occasions on which ritual performances take place. When it comes to basic concepts of design and symbolism, the relationship between the kayon/ gunungan and the pohon beringin is quite remarkable. It is very likely that further research will reveal connections with the indigenous mythologies and visual cultures of the region as a whole. This is also the case in the manner in which these two parallel figures are used during performances.

\section{Endnotes}

1 Quoted in Cook (1974) and Lechler (1937) (Maxwell 1990: 106).

2 From an interview with Pak Nasir, a notable puppet maker from Wakaf Bharu, Kelantan, in April 2017. Pak Nasir, or Che Aziz bin Che Mat, has been an apprentice of the reputable late Dalang Hamzah bin Awang Amat during the 1990s.

3 An interview was done with Pak Rahim bin Hamzah, son of the late Pak Hamzah and also a puppeteer from Tumpat district, Kelantan, in October 2016. Observational studies and photography were made of the late Pak Hamzah's remaining Wayang Kulit Kelantan puppets collection including this arboreal pohon beringin puppet which is currently in the custody of Pak Rahim.

${ }^{4}$ Another interview was done with Pak Eyo Hock Seng, a Chinese dalang from Tumpat district, Kelantan, in October 2016. The authors took photographs of his Wayang Kulit Kelantan puppets which displayed a different style of design in this arboreal pohon beringin puppet.

5 The semen motif is often enriched with a smaller background pattern called isen. Indonesian Batik \& Ikat (1988) indicates "in the semen pattern, one will find fauna, trees... most of these are transformed to some extent, and there are times when a fusion of animal, vegetable and mineral elements seems to flow from the canting" (Indonesian Batik \& Ikat, 1988: 75).

6 The earliest evidence of Muslim influence is an inscribed stone dating from the early $14^{\text {th }}$ century, founding the east coast state of Terengganu (Batik Design: Traditional Textile of the Malay World, 1993: 17 \& 18).

${ }^{7}$ Another interview was done with Pak Yusoff bin Mamat, from Tumpat district, Kelantan, in April 2017. The authors photographed his Wayang Kulit Kelantan puppets which included a pohon beringin puppet which is more figurative in design.

8 There are two types of Javanese kayon or gunungan puppets-gunungan blumbangan and gunungan gapuran. The former comprises "a pond that nourishes the roots of the Cosmic Tree" and "sometimes contains fish" at its lower tier, and is considered as "having female qualities"; whereas the latter consists of "a gate guarded by two jinns, demon giants", and because of its slightly pointed tip, it is considered as "having male qualities" (Irvine, 1996: 98).

${ }^{9}$ Robyn J. and John R. Maxwell in their essay entitled "Political Motives: The Batiks of Mohamad Hadi of Solo" in To Speak with Cloth: Studies in Indonesian Textiles edited by Mattiebelle Gittinger (1989) indicates the difference between the "male" and "female" versions of the gunungan motif as thus: the 'male' type displays an asymmetrical arrangement of animals and a preponderance of Upper World tree patterns above the temple-palace; the 'female' counterpart displays Lower World images in a stylised pond (Gittinger 1989: 37). 
10 The Indian patola, made by means of an elaborate "double ikat" technique, is one of the decorated fabrics from India specially made to suit the tastes prevailing in Southeast Asia. The knowledge of these tastes was acquired through "dialogue and experience in trade", and "Southeast Asian ideas on aesthetics" were incorporated into existing patola designs, resulting in a mixture of local and Indian elements that became the region's favourite patterns. (Batik Design: Traditional Textile of the Malay World, 1993: 44). 


\section{References}

Ainu S. R., Mohd. Azmi. I. (1996). Wayang Kulit: Warisan Teater Melayu. Kuala Lumpur: Perbadanan Kemajuan Kraftangan Malaysia.

Batik Design: Traditional Textile of the Malay World. (1993). Amsterdam and Kuala Lumpur: Pepin Van Roojen.

Chevalier, J. and Gheerbrant, A. (1996). The Penguin Dictionary of Symbols. Translated by John Buchanan-Brown. London: Penguin Books Ltd.

Cuisinier, J. (1957). Le Theatre D’Ombres A Kelantan. 5th edition. Paris: Gallimard.

Fontana, D. (1993). The Secret Language of Symbols: A Visual Key to Symbols and their Meanings. San Francisco: Chronicle Books.

Ghulam-Sarwar, Y. (Ed). (2015). Puppetry for All Times: Papers Presented at the Bali Puppetry Seminar 2013. Singapore: Partridge.

Gittinger, M. (1985). Spendid Symbols: Textiles and Tradition in Indonesia. Singapore: Oxford University Press.

Gittinger, M. ed. (1989). To Speak with Cloth: Studies in the Indonesian Textiles. Los Angeles: Regents of the University of California.

Indonesian Batik \& Ikat. (1988). London: The Hamlyn Publishing Group.

Irvine, D. (1996) Leather Gods \& Wooden Heroes: Java's Classical Wayang. Singapore: Times Editions Pte. Ltd.

Kingham, S. P. J. (2006). "The Kayon in the Shadow Play of Kelantan and Bali." Dimensions of Shadow Play in Malay Civilisation. Ed. Faridah Noor M. N. Kuala Lumpur: Center for Civilisational Dialogue.

Maxwell, R. (1990). Textiles of Southeast Asia: Tradition, Trade and Transformation. Australian National Gallery. Melbourne: Oxford University Press.

Norwani, Md. N. (2016). Ikat Limar: The Ancient Malay Textile. Kuala Lumpur: Dewan Bahasa dan Pustaka.

Rahimidin, Z. (2013). Wayang Kulit Shadow Play: The Folk Epic of the Malay Archipelago. Kuala Lumpur: Institut Terjemahan \& Buku Malaysia.

Skeat, W. W. (1972). Malay Magic. New York: Benjamin Blom.

The Art Institute of Chicago. (2007). The Art of Indonesian Textiles. New Haven and London: Yale University Press.

The Seeker's Glossary of Buddhism. (1998). 2nd Edition. New York: Sutra Translation Committee of the US and Canada 
Malaysian Journal of Performing and Visual Arts, Volume 4, 2018

Thompson, A. (2007). Textiles of South-East Asia. Wiltshire: The Crowood Press Ltd. Wilkinson, R.J. (1957). A Malay-English Dictionary. 2 vols. London: Macmillan.

Tressider, J. (Ed.) (2004). The Complete Dictionary of Symbols in Myth, Art and Literature. London: Duncan Baird Publishers. 